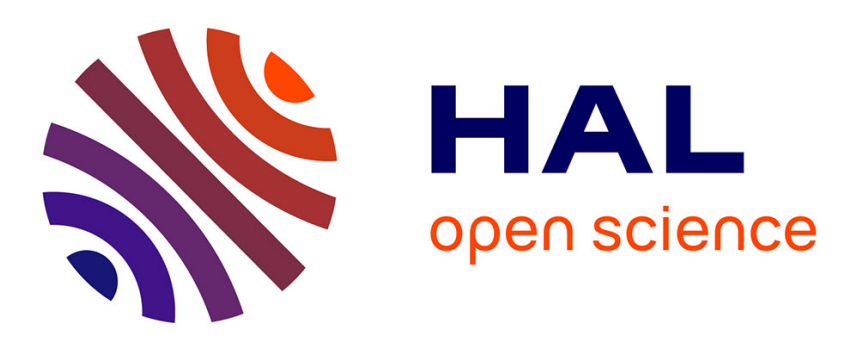

\title{
Study of P Influenced to Magnetic Characteristics of Mn-Zn Ferrites for Power Applications
}

\author{
S. Otobe, T. Hashimoto, H. Takei, T. Maeda
}

\section{To cite this version:}

S. Otobe, T. Hashimoto, H. Takei, T. Maeda. Study of P Influenced to Magnetic Characteristics of Mn-Zn Ferrites for Power Applications. Journal de Physique IV Proceedings, 1997, 07 (C1), pp.C1127-C1-128. 10.1051/jp4:1997141 . jpa-00255088

\section{HAL Id: jpa-00255088 https://hal.science/jpa-00255088}

Submitted on 1 Jan 1997

HAL is a multi-disciplinary open access archive for the deposit and dissemination of scientific research documents, whether they are published or not. The documents may come from teaching and research institutions in France or abroad, or from public or private research centers.
L'archive ouverte pluridisciplinaire HAL, est destinée au dépôt et à la diffusion de documents scientifiques de niveau recherche, publiés ou non, émanant des établissements d'enseignement et de recherche français ou étrangers, des laboratoires publics ou privés. 


\title{
Study of P Influenced to Magnetic Characteristics of Mn-Zn Ferrites for Power Applications
}

\author{
S. Otobe, T. Hashimoto, H. Takei and T. Maeda
}

FDK Corporation, Kosai Factory, 2281 Washizu, Kosai-shi, Shizuoka 431-04, Japan

\begin{abstract}
We examined that influence of $\mathrm{P}$ which changes magnetic characteristics of $\mathrm{Mn}-\mathrm{Zn}$ ferrites for power applications. As quantity of $P$ increase, larger size grains were formed in the microstructure of ferrite and as the result, core loss increased. We found that $P$ had high solubility on ferrite. Therefore, we supposed that $P$ should generate a great deal of liquid phase even if the amount of $P$ is small. Then, the melting point of ferrite-P was relatively low. As the result, we considered that the large grain is caused by liquid phase.
\end{abstract}

\section{INTRODUCTION}

In order to obtain low loss ferrite naterials, it is important to select suitable raw materials and to precisely control of processes. Especially, it is known that impurities contained raw materials have great influence on the electro-magnetic characteristics of ferrites.

In this study, we examined that influence of $P$ which changes magnetic characteristics of $\mathrm{Mn}-\mathrm{Zn}$ ferrites for power applications.

\section{EXPERIMENTAL PROCEDURE}

In this study, we obtained some samples in the following method.

Raw naterials were mixed in a ball mill. The nixture was calcined, and the calcined sample was pulverized in the ball mill. The contents of $P$ of raw materials used in this experiment were less than $10 \mathrm{ppm}$ and the $P$ contents of the ferrite powder made from then were $5 \mathrm{ppm}$. After pulverizing, $\mathrm{P}$ was added to the powder samples with other additives such as $\mathrm{CaO}$ and $\mathrm{SiO}_{2}$. Then each powder sample was pressed into a toroidal shape. All the toroidal samples were sintered at $1350^{\circ} \mathrm{C}$ in controlled oxygen concentration . We measured sintered density, average grain size, electro-resisitivity and core loss of these samples.

\section{RESULTS AND DISCUSSION}

Table 1 shows characteristics of each sample. In this table, hysteresis and eddy current losses were calculated by core lossi $f$-f plots. And Figure 1 shows photographs of microstructure of samples containing 5 and 25 ppm of $P$. As contents of $P$ increased, average grain size became larger because of forming of large size grain caused by abnornal grain growth. In large grains, pore, impurities and additives were entrapped and the novement of magnetic donain wall in large grains was hindered by their obstructions. Consequently, hysteresis loss increased. And because of existence of large grains, average interval of grain boundary region having high resistivity by additives was wide[1]. Therefore, with generation of large grains, 
the resistivity of samples lowered and as the result, eddy current loss increased. We considered that deterioration of the core loss was caused by formation of large grains.

Table 1 Characteristics of samples

\begin{tabular}{|c|c|c|c|c|c|c|}
\hline Contents of $\mathrm{P}$ & (ppm) & 5 & 15 & 25 & 55 & 105 \\
\hline Avg. grain size & $(\mu \mathrm{m})$ & 18.5 & 19.5 & 36.5 & $>100$ & $>100$ \\
\hline Resistivity & $(\Omega \cdot m)$ & 9 & 7 & 5 & 3 & 1 \\
\hline Hysteresis loss & \multirow{3}{*}{$\left(\mathrm{kW} / \mathrm{m}^{3}\right)$} & 147 & 205 & 303 & 367 & 372 \\
\hline Eddy current loss & & 167 & 180 & 226 & 313 & 359 \\
\hline Core loss* & & 314 & 385 & 529 & 680 & 731 \\
\hline
\end{tabular}

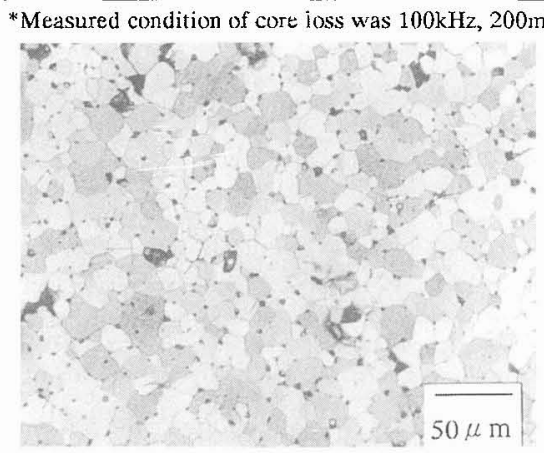

a) P.5ppm

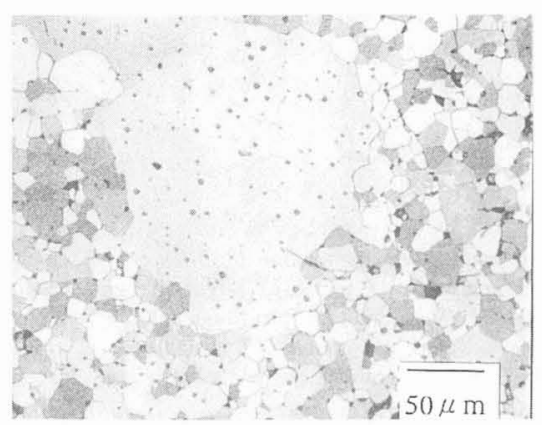

b) P.25ppm

Figure 1 Microscopic photographs of microstructure of samples

Table 2. Results of DTA analysis of mixtures of ferrite and $\mathrm{P}$ or $\mathrm{SiO}_{2}$

\begin{tabular}{|c|c||c|c|}
\hline \multicolumn{2}{|c|}{ Additives } & P 40mol\% & $\mathrm{SiO}_{2} 40 \mathrm{mul} \%$ \\
\hline \hline Mclting point & $(" \mathrm{C})$ & 984 & 1183 \\
\hline$\Delta \mathrm{D} T \mathrm{~A}$ & $(/ / \mathrm{V})$ & 5.85 & 1.41 \\
\hline
\end{tabular}

Table 2 shows results of DTA analysis of nixture of ferrite and $\mathrm{P}$ or $\mathrm{SiO}_{2}$. The compositions of mixtures were ferrite 60 mol\% and $\mathrm{P}$ or $\mathrm{SiO}_{2} 40 \mathrm{~mol} \%$. In both samples, the endothermic reaction peak caused by melting appearcd. Sintering tenperature was sufficiently high compared with the temperature which formed the liquid phase. Therefore, in this experiment, we supposed that $P$ existing locally in sanples was melted with ferrite during sintering. As the result of $\Delta D T A$, we considered that $\mathrm{P}$ dissolved a larger amount of ferrite compared with the same anount of $\mathrm{SiO}_{2}$. Then, the melting point of mixture with added $\mathrm{P}$ was lower than that of $\mathrm{SiO}_{2}$. If liquid phase was formed at a low tenperature, solid phase grains melt into liquid phase easily because the grain size is small and large grain are formed from the liquid phase[2].

In conclusion, we considered that $P$ contained in ferrite generated a large amount of liquid phase at relatively low teniperature during sintering, and the large grains segregated from liquid phase had bad influence on magnetic ellaracteristics.

\section{ACKNOWLEDGMENT}

Many thanks are expressed to Mr. Matsuo and Mr. Tomozawa for their valuable advice and also to Mr. Matse of Tetsugen corporation for his cooperation in preparing iron oxide.

\section{REFERENCES}

[1] T. Mochizuki "RELATIONS BETWEEN MICROSTRUCTURE AND CORE LOSS IN Mn-Zn FERRITES FOR POWER APPLICATIONS", Proceedings of ICF6(1992) pp. 55-56.

[2] N. Yoneda, S. Ito and I. Kato "Duplex structure in oxide magnetic materials (1)", Powder and powder metallurgy, $27(1980)$ pp.6-7. 